\title{
Development of Highly Digestible Grain Sorghum Lines Suitable for Efficient Dry-Grind Ethanol Production
}

\author{
Joan R. Hernandez ${ }^{1}$, Sergio C. Capareda ${ }^{2}$ \\ ${ }^{1}$ iBio CDMO, Inc., Bryan, Texas, USA \\ ${ }^{2}$ Biological and Agricultural Engineering Department, Texas AM University, College Station, Texas, USA \\ Email: scapareda@tamu.edu
}

How to cite this paper: Hernandez, J.R. and Capareda, S.C. (2019) Development of Highly Digestible Grain Sorghum Lines Suitable for Efficient Dry-Grind Ethanol Production. Journal of Sustainable Bioenergy Systems, 9, 98-118.

https://doi.org/10.4236/jsbs.2019.93008

Received: May 22, 2019

Accepted: August 6, 2019

Published: August 9, 2019

Copyright () 2019 by author(s) and Scientific Research Publishing Inc. This work is licensed under the Creative Commons Attribution International License (CC BY 4.0).

http://creativecommons.org/licenses/by/4.0/

\begin{abstract}
Low-world oil prices but supportive government policies provide growing environmental and energy security support favorable for the bioethanol market. The need to generate large and sustainable supply of biomass to make bioethanol will require the development of crops grown specifically for bioenergy production. Given the existing history of genetic improvement and infrastructure available for sorghum, (Sorghum bicolor L. Moench) hybrids will be one of the several species dedicated as energy crop and the subject of this study. Texas A \& M University Sorghum Breeding Program has developed hybrid sorghum varieties with high protein digestibility and improved starch digestibility. Most of the previous research on grain sorghum focused on the digestibility of sorghum protein from the nutritional point of view. The aim of the current study was to select best sorghum lines from relatively large and diverse sorghum samples that breeders are currently working with for the development of new low energy input liquefaction, saccharification and fermentation methodologies to produce bioethanol. Limited researches studies report on the performance of sorghum varieties in ethanol fermentation in relation to the protein and starch digestibility of sorghum.
\end{abstract}

\section{Keywords}

Bioethanol, Dry-Grind, Fermentation, Highly Digestible Grain Sorghum, Saccharification

\section{Introduction}

The worldwide production and consumption of ethanol as an alternative transportation fuel are dramatically increasing in response to growing environmental 
concerns and strengthening economic security. In the United States, bioethanol reduces automotive emissions and as oxygenate substitute for methyl-butyl ether (MTBE). Concerns regarding groundwater contamination prohibit the use of MTBE in gasoline [1]. Since conventional cars produced from the late 1970's can run on gasoline with ethanol amounts of up to 10 percent by volume (E10), ethanol industry has grown at a phenomenal rate. Over 20 million barrels of oil, accounting for two-thirds of the U.S. daily oil consumption, are required just to fuel over 272 million vehicles in America. The U.S. annual production capacity drastically rose from about 2 billion gallons per year in 2000 to nearly 7 billion gallon per year in 2007, with an additional 6 billion gallon per year capacity expected to come in line by the end of 2008 [2].

Brazil and the United States are the world's largest ethanol consumers and producers mainly from sugarcane and cornstarch, respectively. US produce ethanol from bioconversion of corn (70\% starch, along with $9 \%$ protein, $4 \%$ lipids and $9 \%$ fiber on a dry weight basis) via two methods, dry grind and wet mill (Figure 1) [3]. In wet milling, one separates kernels into components and only the starch portion is fermented. In dry-grind process, one would grind whole kernels to flour and feed directly into the fermentation process. Though wet milling produces more co-products such as oil, gluten meal and gluten feed, it requires higher capital and operating cost than dry grind process [4]. Thus, most of the expansion of the ethanol industry is in new and large dry grind ethanol

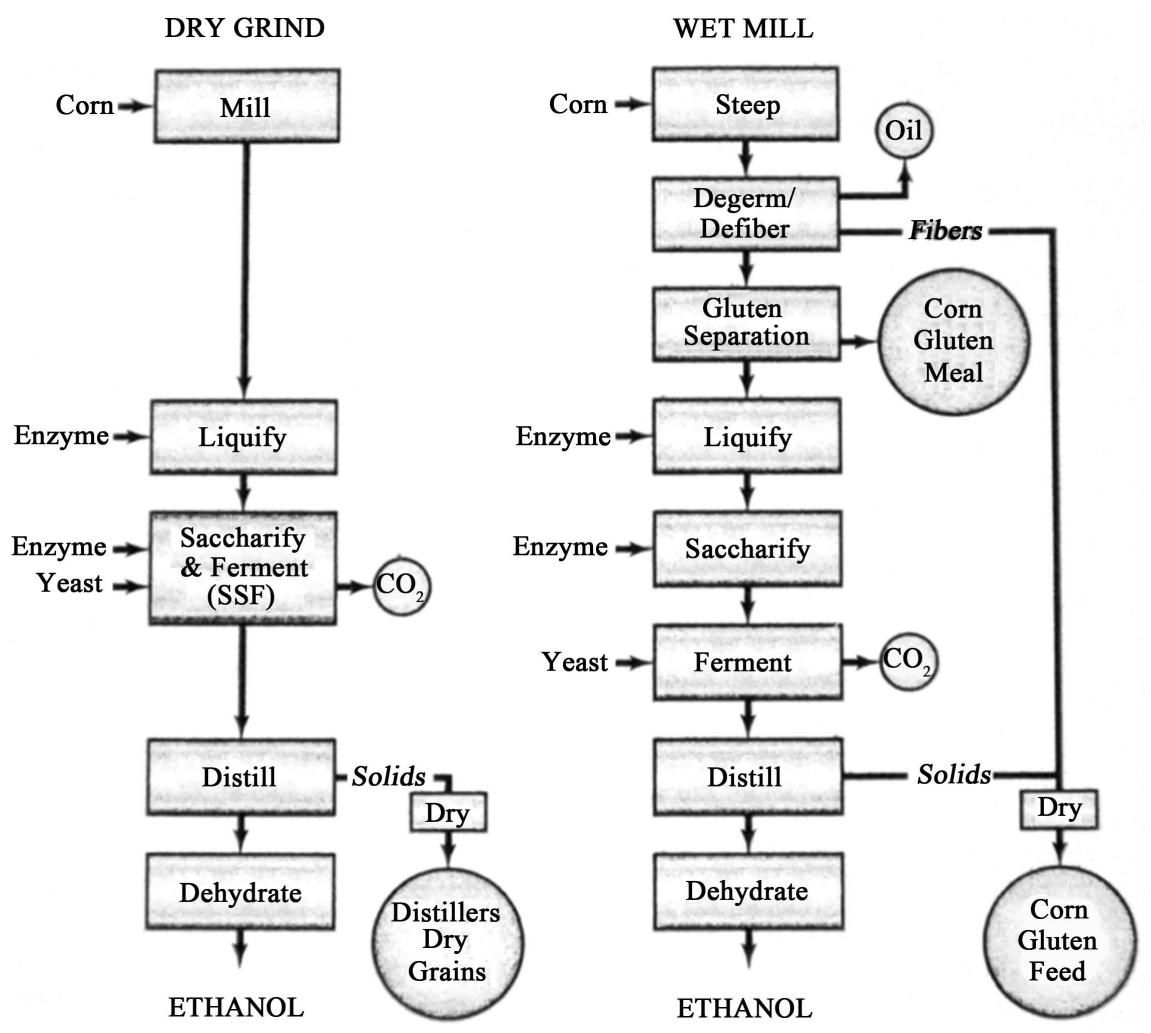

Figure 1. Comparison of the dry grind and wet mill processes for production of ethanol [3]. 
plants. In 2006, $82 \%$ of the US ethanol-producing capacity was in dry-grind facilities and $18 \%$ was in wet milling plants [5]. Dry grind facilities produce 2.7 to 2.8 gallons $(10.4 \mathrm{~L})$ per bushel $(25.5 \mathrm{~kg})$ of corn, as well as a co-product animal feed called distillers dried grains with soluble (DDGS). One would recover DDGS at the end of the process. The DDGS contains yeast and non-fermentable parts of the corn like germ, fiber, and protein [4].

In a conventional dry-grind process, basic processes involve grinding, cooking, liquefaction, saccharification, fermentation, distillation and co-product recovery. Corn is ground and mixed with water to produce slurry. Slurry is cooked to breakdown the crystalline structure of starch granules and the resulting mash is further liquefied and saccharified by amylase enzymes to reduce viscosity and to produce sugars, respectively. The fermentable sugars produced are then converted to ethanol by yeast during fermentation [6] and [7].

The combination of low corn prices, high energy prices, and strong ethanol demand encouraged by various government measures, stimulated the rapid expansion of corn-based ethanol production. This profitable growth in ethanol production substantially increased the demand for corn and is deemed to be the main factor that drove the price of corn up by approximately $90 \%$ from August 2006 to February 2007. The current price of ethanol is around $\$ 2.50$ a gallon while the corn price has already reached a record of US $\$ 6$ a bushel. Such increase is good news for corn growers, but a burden for ethanol producers. If the selling price of ethanol stays the same, and the cost of corn used in production increases, it is estimated that profit from ethanol processing would decrease from US $\$ 1.06$ per gallon to a net average of US $\$ 0.03$ per gallon.

Since corn is also used as food and feed source, there is a need to develop a dedicated bio-energy crop to generate a large, sustainable and low-cost feed stocks supply that will fit the existing fermentation infrastructure. Currently, interest in the utilization of sorghum in bio-industrial applications is growing in the U.S. Researchers and ethanol producers have shown that grain sorghum is a reasonable feedstock for ethanol since it is cheaper, more drought-tolerant than corn and it can fit the existing fermentation infrastructure. On a well manage planting dates, grain sorghum offers exceptional rotation crop for corn and cotton because it provides ample residue for conservation-tillage system and potential yield for South Texas farmers [8]. In conservation tillage system, previous crop's residues are purposely left on the soil surface to conserve soil and for more efficient water use to get higher yields for crops grown without irrigation in drought-prone soils like in semiarid regions [9].

Approximately 82 percent of the sorghum seed structure is the grain endosperm [10] which is comprised of cells containing protein bodies trapped in a protein matrix that surrounds the larger starch granules [11]. Although grain sorghum has a chemical composition similar to corn, it has been underutilized for bio-based products and bio-energy production due to its poor wet-milling properties [12] and low ethanol yield relative to corn. Compared with other ce- 
reals such as wheat and corn, sorghum is well known for its poor digestibility and low nutritional value, especially after wet-cooked. Although the cause of poor digestibility of sorghum proteins and starches is not yet fully understood, several plausible explanations have been proposed. Some [13] based their explanations on the interaction of the prolamins with polyphenolic tannins and starch and the protein cross-linking in response to $\mathrm{pH}$ or temperature changes in the surrounding environment. With the several proposed factors, the starch being imbedded in the protein body (kafirin) matrices, which restrict gelatinization, is the predominant theory why normal grain sorghum has low protein and starch digestibility.

Sorghum breeders are working with thousands of sorghum genotypes with diverse genetic backgrounds, chemical, and physical properties. Most of the previous research on grain sorghum was focused on the digestibility of sorghum protein from the nutritional point of view [13] [14] [15] and [16]. Not much research has been conducted on the performance of sorghum varieties in ethanol fermentation in relation to the protein and starch digestibility of sorghum. By understanding and analyzing the relationship among the key factors impacting on the bio-processing of sorghum, the best sorghum genotypes with high conversion efficiency for ethanol production could be identified. This will assist the breeders in the development of new and improved sorghum hybrids for ethanol production and will increase the production and utilization of sorghum to meet the enormous feedstock demand of the future ethanol industry.

Recently, the Sorghum Breeding Program at the Soil and Crop Science Department, Texas A \& M University has developed and identified high digestible grain sorghum (HDGS) genotypes with modified endosperm matrices that lack the kafirin protein body highways. HDGS genotypes are hypothesized to have several added benefits (low energy input during gelatinization prior and higher lysine protein content than corn), making these cultivars a suitable alternative for corn in the typical bio-ethanol-feed supplement system. The aim of the current study was to select the best sorghum lines from relatively large and diverse sorghum samples that breeders are currently working on for the development of new low energy input liquefaction, saccharification and fermentation methodologies to produce ethanol.

The objectives of this research are as follows:

1) To investigate the effect of grain sorghum protein digestibility on the temperature and time of starch gelatinization as well as on the rate and efficiency of enzymatic saccharification;

2) To evaluate the performance of the improved sorghum hybrids in ethanol fermentation via simultaneous saccharification and fermentation using dry yeast (Ethanol Red) from Fermentis and high concentration of dry solid (30\%); and

3) To identify the key factors (chemical and physical properties, flour particle size, starch pasting property, yeast viability, enzyme and substrate concentration) affecting ethanol yield. 


\section{Materials and Methods}

\subsection{Grain Sorghum Lines Used as Substrates}

First, eighteen recombinant inbred lines (RILs) of grain sorghum (parent lines and offsprings) were used in this study. These were grown and harvested from Welasco, Texas in 2006. Two parent lines of highly digestible protein (HD) grain sorghum (P850029 and P851171) with high lysine content were crossed with three parent lines of wild type (WT) grain sorghum (B.Tx635, R.Tx436 and 96GCPOB124) with high grain mold disease resistance to develop three families with four distinct RILs. The lines were phenotyped as highly digestible (HD), medium digestible (MD) and of normal digestible (ND) protein using the protease turbidity assay [17]. The resulting phenotype group defined as one or more RILs with absorbances (after 60 min of dilution in 72\% Trichloro Acetic Acid) not significantly different according to Tukey's HSD at a 0.05 level of significance is shown in Figure 2. Approximately $2 \mathrm{~kg}$ seeds of each RILs were collected, cleaned and ground (Cyclone Sample Mill, UDY Corp.) into flour with a particle size of less than $1 \mathrm{~mm}$. They were used as the substrates for saccharification and ethanol fermentation.

\subsection{Physical Properties and Chemical Composition of the Sorghum Grains}

The physical properties, (endosperm texture index, seed hardness index, and kernel weight) and chemical compositions (starch, protein and moisture) of the sorghum grains were determined by the Sorghum Breeding Laboratory at Soil and Crop Science Department, Texas A \& M University [17]. Endosperm texture

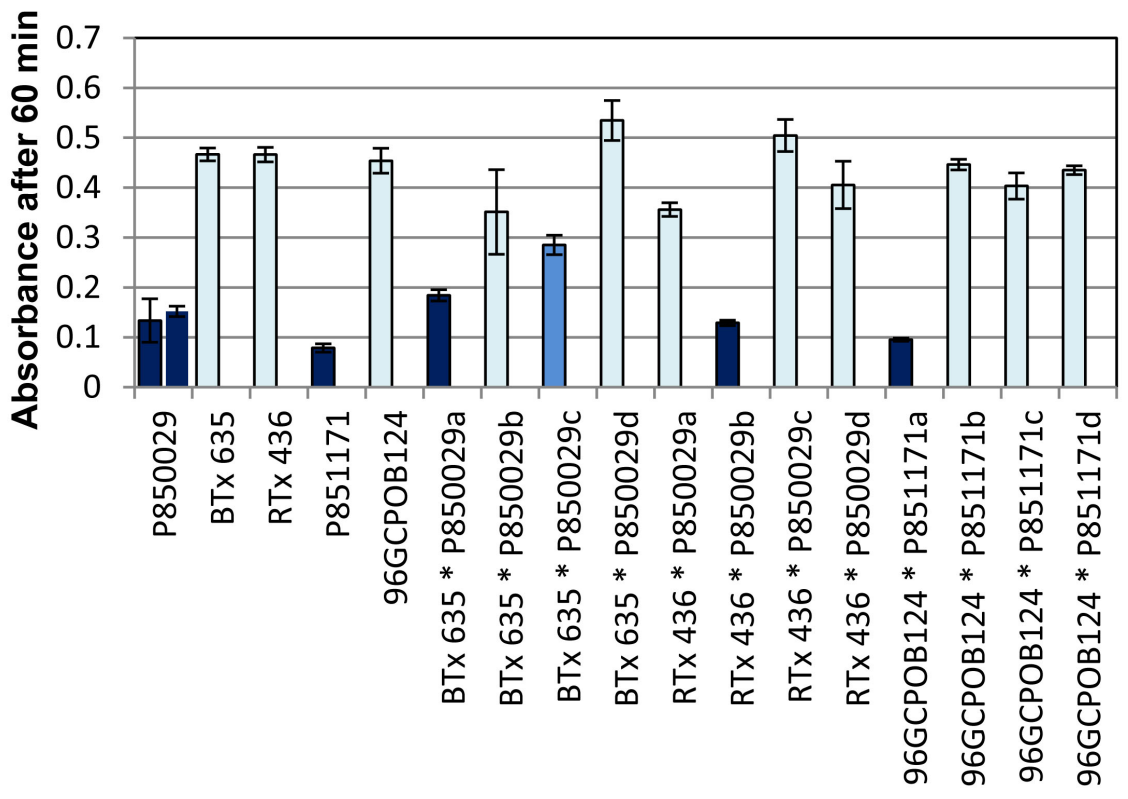

Grain Sorghum Breed Lines

Figure 2. Digestible group based on 60 min turbidity assay. (Protein digestibility: $\mathrm{HD}$; $\mathrm{MD}$; and $\square$ ND.) 
index was categorized as described by [18] from 1 (flinty endosperm) to 5 (chalky endosperm) via visual examination of longitudinal half kernels while seed hardness index was characterized using the single kernel hardness test (SKHT) (Perten Single Kernel Characterization System SKCS 4100, Perten Instruments, Springfield IL). The average starch, protein and moisture content of the grains were determined using near-infrared reflectance (NIR) spectrophotometry (Perten PDA 7000 Dual Array with Grams Software, Perten Instruments, Springfield IL). Ash analysis was conducted according to ASTM standard E 1755-01, Standard Test Method for Ash in Biomass (ASTM, 2001a). The moisture content of flour was determined in accordance with Approved AACC Methods 44-15A [19].

\subsection{Sorghum Flour Tasting Profile}

The pasting properties of sorghum flours were evaluated using the Rapid-Visco-Analyzer (RVA, Newport Scientific PTY, Ltd., Warriewood, Australia) through the classic heat-hold-cool process. About $28 \mathrm{~g}$ mixture of sorghum flour (4.2 g flour d.b.) and water was prepared and equilibrated at $50^{\circ} \mathrm{C}$ temperature. The suspension was then heated to and held at $95^{\circ} \mathrm{C}$ and then cooled again to $50^{\circ} \mathrm{C}$. This caused the starch granule swelling, disruption and polymer re-association. The total test time was $13 \mathrm{~min}$ with viscosity and temperature readings taken every $2 \mathrm{sec}$. The study measured the following:

1) Peak viscosity [maximum paste viscosity achieved in the heating stage],

2) Trough viscosity [minimum paste viscosity achieved after holding at the maximum temperature],

3) Final viscosity [viscosity at the end of run],

4) Pasting temperature [starch granules begin to swell and gelatinize due to water uptake], and,

5) Peak time [when peak viscosity was recorded] were all measured and recorded.

The study also calculated the breakdown and setback from the difference between the peak and trough viscosity and the final and trough viscosity, respectively. Due to large number of sample set, the study duplicated all runs and reported average values. The study described the flour pasting profiles.

\subsection{Particle Size Distribution}

The particle size distribution (PSD) of the sorghum flour samples was analyzed in triplicate using the Malvern Instruments Mastersizer 2000 (Malvern Instruments Ltd., Mastersizer 2000, Worcestershire, UK). The instrument measures particle size based on light scattering (Mie) and is able to analyze both wet and dry samples in the range of 0.02 to $2000 \mu \mathrm{m}$. Red light is used to produce forward, side, and back scattering while a blue light is used to produce wide angle forward and back scattering of light once it hits the particles. Thousands of light scatter patterns collected by the instrument were used to develop the relation- 
ship between percent volume and the equivalent spherical diameter (ESD). The ESD was then converted to AED (Aerodynamic equivalent diameter) using Equation (1).

$$
\mathrm{AED}=\mathrm{ESD} \sqrt{\frac{\rho_{p}}{\chi}}
$$

where

$\mathrm{AED}=$ aerodynamic equivalent diameter,

$\mathrm{ESD}=$ equivalent spherical diameter,

$\rho_{p}=$ particle density $\left(\mathrm{g} / \mathrm{cm}^{3}\right)$, and

$\chi=$ shape factor.

The particle density of the samples was measured using the AccuPyc 1330 (Micromeritics, AccuPyc 1330 Pycnometer, Norcross, GA) pycnometer by the gas displacement method. The pycnometer releases helium of known volume into a container of fixed volume. The difference between the two volumes represents the volume of the particles inside the container. The mass was measured before inserting the sample into the pycnometer. The density was then calculated using Equation (2),

$$
\rho=\frac{m}{V}
$$

where

$$
\begin{aligned}
& \rho=\text { particle density of sample }\left(\mathrm{g} / \mathrm{cm}^{3}\right), \\
& m=\text { mass of sample }(\mathrm{g}) \text {, and } \\
& V=\text { volume of material sample less open void space }\left(\mathrm{cm}^{3}\right) .
\end{aligned}
$$

Particle size distribution is a log-normal distribution that uses mass median diameter (MMD) as the geometric mean (calculated AED at $d_{50 \%}$ ) and geometric standard deviation (GSD) in describing how spread out are the particle size. MMD is the particle size in which $50 \%$ of the overall particles by weight are smaller than the MMD and 50\% are larger than half of the mass [20]. The GSD is calculated using Equation (3),

$$
\mathrm{GSD}=\sigma_{g}=\frac{d_{84.1 \%}}{d_{50 \%}}=\frac{d_{50 \%}}{d_{15.9 \%}}=\sqrt{\frac{d_{84.1 \%}}{d_{15.9 \%}}}
$$

where $d_{n \%}$ is the particle size in which $n$ percent of the mass is contributed by particles less than $d$.

\subsection{Saccharification of Sorghum Starch Using Enzyme}

The enzymatic conversion of starch to fermentable glucose units was based on the modified NREL LAP-016, National Renewable Energy Laboratory-Laboratory Analytical Procedure [21]. In this study, the enzymes used were alpha-amylase (SPEZYME ${ }^{\circ}$ XTRA) and gluco-amylase $\left(\mathrm{G}^{-Z} \mathrm{YME}^{\circ} 480\right.$ Ethanol) provided by Genencor International, Incorporated. One Alpha Amylase Unit (AAU) of bacterial $\alpha$-amylase represents the amount of enzyme required to hydrolyze $10 \mathrm{mg}$ starch per minute while one Gluco-amylase Unit (GAU) is the amount of en- 
zyme needed to release one gram of glucose per hour from soluble starch substrates.

Two sets of incubation time and enzyme concentration were used to determine the conversion rate and conversion efficiency of starch to glucose. For conversion rate determination, enzyme solution of $0.2 \mathrm{~mL}$ of $\alpha$-amylase and 0.2 $\mathrm{ml}$ glucoamylase each diluted to $50 \mathrm{ml}$ using sodium acetate buffer were used while $2 \mathrm{ml}$ of $\alpha$-amylase and $2 \mathrm{ml}$ gluco-amylase diluted to $25 \mathrm{ml}$ were prepared for conversion efficiency analysis. The samples were prepared in duplicate for conversion rate determination and triplicate for the conversion efficiency analysis.

Using a tared $15 \mathrm{ml}$ plastic centrifuge with a tightly fitting screw cap, $100 \mathrm{mg}$ of ground samples from each RIL was mixed with $0.2 \mathrm{~mL} 190$ proof ethanol and $2 \mathrm{ml}$ dimethyl sulfoxide (DMSO). The sample mixture was vortexed vigorously to aid starch dispersion and then incubated in a briskly boiling water bath for 5 min to gelatinize the starch. It is then acidified with $2.9 \mathrm{ml}$ sodium acetate buffer (pH 4.5 containing $11.8 \mathrm{ml}$ glacial acetic acid per liter solution) and $0.1 \mathrm{ml}$ thermostable alpha-amylase solution (6.38 AAU and 127.68 AAU) was added. To liquefy the starch, the mixture was then incubated at $80^{\circ} \mathrm{C}$ using VWR digital water shaking at 300 strokes per min (for $6 \mathrm{~min}$ and $10 \mathrm{~min}$ ). Another $4 \mathrm{ml}$ sodium acetate buffer and $0.1 \mathrm{ml}$ gluco-amylase (0.17 GAU and 3.46 GAU) were added and then incubated at $50^{\circ} \mathrm{C}$ (for $30 \mathrm{~min}$ and $60 \mathrm{~min}$ ) to saccharify the hydrolyzed starch. The samples that were tightly capped throughout the analysis had a final volume of $9.3 \mathrm{ml}$.

\subsection{Sugar Analysis}

Using $2 \mathrm{ml}$ Eppendorf tubes, about $1.5 \mathrm{ml}$ of the saccharified aliquot was heated for $2 \mathrm{~min}$ in a briskly boiling water to deactivate the enzyme. We cool the sample and then centrifuged at $3000 \mathrm{rpm}$ for $10 \mathrm{~min}$ at a temperature of $25^{\circ} \mathrm{C}$. We filter the samples through $0.22 \mu \mathrm{m}$ membrane filter prior to HPLC analysis. The Waters Alliance ${ }^{\oplus}$ Model HPLC system (Waters Corporation, Milford, MA) with 2690 Separation Modules (integrates five 24-vial carrousel, solvent delivery system, onboard controller, compartment for column and column heater) and Waters $2410 \mathrm{RI}$ detector were used for the analysis of glucose conversion. RI detectors use monochromatic light (wavelength around $400 \mathrm{~nm}$ ). The Shodex SP0810 column $(8.0 \mathrm{~mm}$ id $\times 300 \mathrm{~mm})$ equipped with SP-G guard column $(6.0 \mathrm{~mm}$ id $\times$ $50 \mathrm{~mm}$ ) were used at column temperature of $60^{\circ} \mathrm{C}$ using filtered and degassed deionized water as the eluent at $0.7 \mathrm{ml} / \mathrm{min}$. Each sample was analyzed for 30 min and standards were run at the start, middle and end of sample analysis. For quality assurance, $20 \%$ of the samples were analyzed in duplicate and a blank was run every 10 sample injections.

\subsection{Fermentation}

Thirty five (35) g sorghum flour samples (equivalent to about $30 \mathrm{~g}$ dry mass) were mixed with $60 \mathrm{~mL}$ of sterilized and deionized water in sterilized $250 \mathrm{ml} \mathrm{Er}$ - 
lenmeyer flask with cotton plug. The starch was gelatinized for $1 \mathrm{~h}$ in a boiling water bath while shaking at 150 strokes per minute using the VWR digital shaking water bath. First dosing of SPEZYME XTRA $(0.02 \% \mathrm{w} / \mathrm{w}$ of dry substrate) was added before the gelatinization stage of the starch to reduce the viscosity while cooking. The enzyme solutions for liquefaction and saccharification were prepared separately by diluting $1 \mathrm{ml}$ of SPEZYME XTRA and $2 \mathrm{~mL} \mathrm{G-ZYME}{ }^{\circ}$ 480 Ethanol to $100 \mathrm{ml}$ using sodium acetate buffer. After cooking, the mixture was adjusted to $\mathrm{pH} 5.5$ using $1 \mathrm{~N} \mathrm{NaOH}$ and $1 \mathrm{~N} \mathrm{H}_{2} \mathrm{SO}_{4}$ solution. Another $5 \mathrm{ml}$ of sterilized and deionized water was added to reduce the temperature of the mixture to about $80^{\circ} \mathrm{C}$ before the second dosing of SPEZYME ${ }^{\circ}$ XTRA $(0.02 \%$ $\mathrm{w} / \mathrm{w}$ of dry substrate). Liquefaction at $80^{\circ} \mathrm{C}$ was continued in the shaking water bath for $30 \mathrm{~min}$ at $150 \mathrm{rpm}$. Before adding G-ZYME 480 Ethanol enzyme $(0.1 \%$ $\mathrm{w} / \mathrm{w}$ of dry solid), $5 \mathrm{ml}$ of sterilized and deionized water was again added to reduce the temperature of the mixture to about $65^{\circ} \mathrm{C}$. Saccharification with G-ZYME 480 Ethanol was done for $30 \mathrm{~min}$ at $60^{\circ} \mathrm{C}$, after which, flasks were removed from the water bath and cooled for another $30 \mathrm{~min}$ until the hydrolyzate attained $35^{\circ} \mathrm{C}$.

After 30 min saccharification and cooling to room temperature, the fermentation medium was inoculated with $2.0 \mathrm{~mL}$ of activated dry yeast (Ethanol Red) from Fermentis. To activate the Ethanol Red, $5.00 \mathrm{~g}$ of dry yeast in $25 \mathrm{~mL}$ of sterilized peptone saline water ( $8.5 \mathrm{~g}$ of $\mathrm{NaCl}$ and $1 \mathrm{~g}$ of peptone per liter) was incubated in New Brunswick shaker incubator (New Brunswick Scientific Inc., Edison, NJ) at $150 \mathrm{rpm}$ and $32^{\circ} \mathrm{C}$ for $25 \mathrm{~min}$. The activated yeast suspension had a live cell concentration of about $1.0 \times 10^{9}$ cells $/ \mathrm{mL}$ while the inoculated mash had a yeast cell concentration of approximately $1.0 \times 10^{7}$ cells $/ \mathrm{mL}$. Fermentation set up for each grain sample was done in duplicate and were incubated in the rotary shaker at $150 \mathrm{rpm}$ and $32^{\circ} \mathrm{C}$ for $72 \mathrm{~h}$.

\subsection{Ethanol and Yeast Viability Analysis}

Using a $3 \mathrm{ml}$ sterile syringe, exactly $1 \mathrm{ml}$ of the sample from each fermentation flasks was taken after 24,48 and $72 \mathrm{~h}$ of yeast inoculation. The collected sample was diluted with $9 \mathrm{ml}$ sterilized deionized water in a sterilized $15 \mathrm{ml}$ test tube with cap and used for microbial and ethanol analysis.

For microbial analysis, $1 \mathrm{ml}$ of the diluted sample was serially dilution in sterilized test tube with cap and peptone saline water. Using Plate Count Agar (PCA) containing $1 \mathrm{~g} / \mathrm{L}$ glucose, $2.5 \mathrm{~g} / \mathrm{L}$ yeast extract, $5 \mathrm{~g} / \mathrm{L}$ tryptone, and $15 \mathrm{~g} / \mathrm{L}$ agar, $100 \mu \mathrm{L}$ aliquot from the $10^{-5}$ dilution was immediately plated in duplicate for yeast viability analysis. Spread plates were inverted and incubated at $35^{\circ} \mathrm{C}$ for $48 \mathrm{~h}$. Plates having a colony forming units ( $\mathrm{cfu}$ ) between 30 and 300 were used for the analysis.

The remaining $9 \mathrm{ml}$ of the diluted sample was transferred into a $15 \mathrm{ml}$ plastic centrifuge with a tightly fitting screw cap. After centrifugation at $3000 \mathrm{rpm}$ for $10 \mathrm{~min}$, the supernatant was filtered through $0.22 \mu \mathrm{m}$ membrane filter prior to HPLC analysis for ethanol. The HPLC condition, column and detector were the 
same as during sugar analysis. The fermentation efficiency was calculated from the theoretical yield of $56.72 \mathrm{~g}$ of ethanol produced from $100 \mathrm{~g}$ of dry starch assuming $1 \mathrm{~g}$ of starch could be hydrolyzed into $1.11 \mathrm{~g}$ glucose, and each gram of glucose could produce $0.511 \mathrm{~g}$ of ethanol.

\subsection{Statistical Analysis}

Eighteen recombinant inbred lines (RILs) of grain sorghum were grouped as HD and ND for both parent lines and offsprings. Using SPSS 16, analysis of variance (ANOVA) for individual variables was performed for each digestible group. Using the least squares difference (LSD), the significance of variation among means of each digestible group was determined. Pearson correlation was also used to relate pasting parameters, particle size and physicochemical properties of the grain with glucose and ethanol yield. The level of significance was $\mathrm{P}<0.05$ for statistical methods, except as noted.

\section{Results and Discussions}

\subsection{Physical Properties and Chemical Composition of the Sorghum Grains}

The average values of the physical properties and chemical composition of each digestible group (parent and offspring sorghum grain samples) are shown in Table 1. The analysis of variance (ANOVA) (Table 2) showed that there are significant differences in starch content, kernel hardness and kernel texture among the digestible groups. Least significant difference (LSD) test (Table 1) reveals that both parent and offspring from the same digestible group were not significantly different in both chemical and physical properties and only the starch content, kernel hardness and endosperm texture of the HD group were significantly different from those of the ND group ( $\mathrm{p}$ values $<0.05$ ). The HD

Table 1. Physical properties and chemical composition of the sorghum grain samples.

\begin{tabular}{|c|c|c|c|c|}
\hline \multirow{3}{*}{ Properties } & \multicolumn{4}{|c|}{ Digestible Group } \\
\hline & \multicolumn{2}{|c|}{ Parent } & \multicolumn{2}{|c|}{ Offspring } \\
\hline & HD & ND & HD & ND \\
\hline \multicolumn{5}{|l|}{ Chemical } \\
\hline Starch $(\% \mathrm{db})$ & $80.21^{\mathrm{a}}$ & $83.33^{\mathrm{b}}$ & $80.10^{\mathrm{a}}$ & $83.82^{\mathrm{b}}$ \\
\hline Protein (\% db) & $15.09^{\mathrm{a}}$ & $15.86^{\mathrm{a}}$ & $15.08^{\mathrm{a}}$ & $15.40^{\mathrm{a}}$ \\
\hline Moisture (\% wb flour) & $11.49^{\mathrm{a}}$ & $11.69^{\mathrm{a}}$ & $11.63^{\mathrm{a}}$ & $11.55^{\mathrm{a}}$ \\
\hline Ash (\% db) & $2.16^{\mathrm{a}}$ & $1.73^{\mathrm{a}}$ & $1.74^{\mathrm{a}}$ & $1.94^{\mathrm{a}}$ \\
\hline \multicolumn{5}{|l|}{ Physical } \\
\hline Kernel size (mm) & $2.06^{\mathrm{a}}$ & $2.13^{\mathrm{a}}$ & $1.99^{\mathrm{a}}$ & $2.28^{\mathrm{a}}$ \\
\hline Kernel hardness (index) & $34.86^{\mathrm{a}}$ & $81.50^{\mathrm{b}}$ & $33.16^{\mathrm{a}}$ & $78.59^{\mathrm{b}}$ \\
\hline Endosperm Texture & $5^{\mathrm{a}}$ (Chalky) & $2^{\mathrm{b}}$ (Flinty) & $5^{\mathrm{a}}$ (Chalky) & $2^{\mathrm{b}}$ (Flinty) \\
\hline Flour Density $\left(\mathrm{g} / \mathrm{cm}^{3}\right)$ & $1.4319^{\mathrm{a}}$ & $1.4278^{\mathrm{a}}$ & $1.4315^{\mathrm{a}}$ & $1.4274^{\mathrm{a}}$ \\
\hline
\end{tabular}

Note: Means with the same letter in the same row are not significantly different using LSD $(\alpha=0.05)$. 
Table 2. Mean squares from ANOVA of physical and chemical properties among digestible group.

\begin{tabular}{cccccc}
\hline & Sum of Squares & df & Mean Square & F & Sig. \\
\hline Starch (\%db) & 151.3797 & 3 & 50.45989 & 15.88834 & 0.00000 \\
Protein (\%db) & 3.683034 & 3 & 1.227678 & 0.887038 & 0.45429 \\
Ash (\%db) & 1.117074 & 3 & 0.372358 & 1.583905 & 0.20492 \\
Endosperm Texture & 68.11111 & 3 & 22.7037 & 408.6667 & 0.00000 \\
Kernel Hardness (index) & 24701.61 & 3 & 8233.869 & 102.4416 & 0.00000 \\
Flour Moisture (\% wb) & 0.218217 & 3 & 0.072739 & 0.757655 & 0.52318 \\
Kernel Size (mm) & 0.244467 & 3 & 0.081489 & 2.811809 & 0.07779 \\
\hline
\end{tabular}

sorghum lines had significantly lower starch content and kernel hardness index than ND sorghum lines. In addition, the HD group exhibited chalky endosperm texture compared to the flinty texture of the ND group. Table 1 further indicates that there were no significant differences in the protein, moisture and ash content, kernel size and flour density between the digestible groups. However, the HD lines had more flour-like endosperm texture, softer kernels and lower starch content than the ND lines.

\subsection{Sorghum Flour Pasting Profile}

The average peak viscosity, breakdown, setback, peak time and pasting temperature of the sorghum groups measured during the 13-min heat-hold-cool process are shown in Table 3 while representative pasting curves of several HD and ND RILs (parents and offspring) from the 18 sorghum cultivars generated from the viscosity data are shown in Figure 3 . The temperature profile during pasting is indicated by the solid straight line at the top of the RVA curves. While the RVA curves appeared to follow the same pattern, there were still observed differences between HD and ND groups. However, LSD test showed that pasting properties of both parent and offspring from the same digestible group were not significantly different.

The ANOVA showed significant differences at 95\% confidence level between the $\mathrm{HD}$ and ND groups in peak time, pasting temperature, peak viscosity, trough, breakdown and setback but not in the final viscosity (Table 4). The initial swelling temperature of HD sorghum starches was significantly lower $\left(77^{\circ} \mathrm{C}\right)$ than that of ND cultivars $\left(83^{\circ} \mathrm{C}\right)$ and $\mathrm{HD}$ lines also took less time $(4.86 \mathrm{~min})$ to reach peak viscosity than ND lines $(5.58 \mathrm{~min}$ ) (Table 3 ). There was no significant difference in the final viscosity among the digestible group, despite the significant difference in starch content. The HD lines had lower pasting temperature and faster rate of gelatinization compared to the ND lines. Thus, HDGS may require lower energy input during gelatinization and hydrolysis of starch granules and increase the bio-availability of starch during enzymatic hydrolysis prior to ethanol fermentation. This provides an advantage of the HD lines if used as a feedstock for ethanol production. 


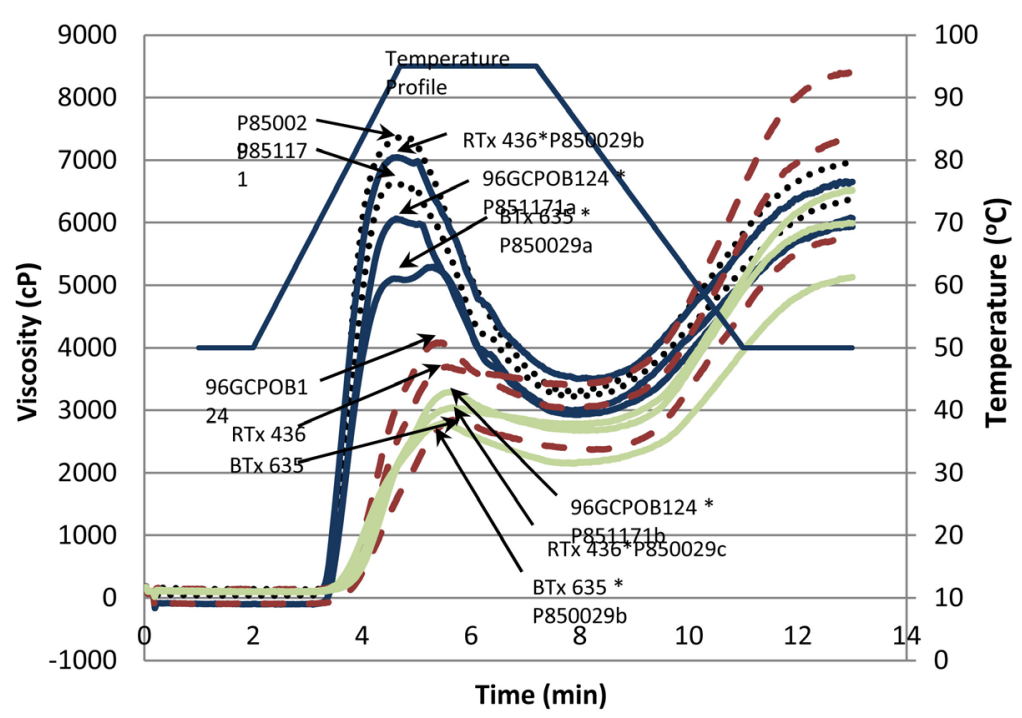

Figure 3. RVA curves of HD and ND sorghum samples selected from 18 cultivars using the 13-min temperature profile. ( $\cdots$ HD parent; - HD offspring; -2 ND parent; and ND offspring.)

Table 3. RVA parameters for ND and HD RILs using the 13-min temperature profile among digestible groups.

\begin{tabular}{|c|c|c|c|c|}
\hline \multirow{3}{*}{ RVA Properties } & \multicolumn{4}{|c|}{ Digestible Group } \\
\hline & \multicolumn{2}{|c|}{ Parent } & \multicolumn{2}{|c|}{ Offspring } \\
\hline & HD & ND & HD & ND \\
\hline Peak Viscosity (cP) & $6920^{\mathrm{a}}$ & $3540^{\mathrm{b}}$ & $6134^{c}$ & $3194^{\mathrm{b}}$ \\
\hline Trough (cP) & $3232^{\mathrm{a}}$ & $2935^{\mathrm{a}, \mathrm{b}}$ & $3136^{\mathrm{a}}$ & $2656^{\mathrm{b}}$ \\
\hline Breakdown (cP) & $3688^{a}$ & $605^{\mathrm{b}}$ & $2998^{c}$ & $537^{\mathrm{b}}$ \\
\hline Setback (cP) & $3214^{a}$ & $4222^{\mathrm{b}}$ & $3080^{\mathrm{a}}$ & $3528^{\mathrm{a}, \mathrm{b}}$ \\
\hline Final Viscosity (cP) & $6446^{\mathrm{a}}$ & $7157^{\mathrm{a}}$ & $6217^{\mathrm{a}}$ & $6185^{\mathrm{a}}$ \\
\hline Peak Time (min) & $4.64^{\mathrm{a}}$ & $5.58^{\mathrm{b}}$ & $4.86^{\mathrm{c}}$ & $5.62^{\mathrm{b}}$ \\
\hline Pasting Temperature $\left({ }^{\circ} \mathrm{C}\right)$ & $77.19^{\mathrm{a}}$ & $82.84^{\mathrm{b}}$ & $77.26^{\mathrm{a}}$ & $83.06^{\mathrm{b}}$ \\
\hline
\end{tabular}

Note: Means with the same letter in the same row are not significantly different using LSD $(\alpha=0.05)$.

Table 4. Mean squares from ANOVA of starch pasting properties among digestible groups.

\begin{tabular}{cccccc}
\hline & Sum of Squares & $\mathrm{df}$ & Mean Square & $\mathrm{F}$ & Sig. \\
\hline Peak_viscosity & $8.67 \mathrm{E}+07$ & 3 & $2.89 \mathrm{E}+07$ & 107.298 & 0.0000 \\
Pasting_temp & 12.382 & 3 & 4.127 & 15.928 & 0.0000 \\
Peak_time & 6.062 & 3 & 2.021 & 74.464 & 0.0000 \\
Final_viscosity & $4,486,622.668$ & 3 & 1495541 & 2.79 & 0.0560 \\
Trough & $2,054,084.632$ & 3 & $684,694.9$ & 7.445 & 0.0010 \\
Breakdown & $6.37 \mathrm{E}+07$ & 3 & $2.12 \mathrm{E}+07$ & 163.079 & 0.0000 \\
Setback & $4,678,934.658$ & 3 & 1559645 & 6.773 & 0.0010 \\
\hline
\end{tabular}


The HD RILs started to gelatinize and liquefy at lower temperatures and in shorter time than the normal endosperm RILs. The differences in swelling temperatures and gelatinization rate is possibly a result of genetic variation in varieties' kernel structures like more floury endosperm and increased protein digestibility attributed to the folded conformation of the endosperm protein bodies. The above results suggest that as protein digestibility increases, the pasting properties of flour also improve. According to [14], grain floury endosperm texture was significantly and negatively correlated with starch amylose content. Turbidity level, which is inversely related to protein digestibility, was also significantly correlated with pasting temperature ( $\mathrm{p}$ value $<0.001$ ), peak viscosity ( $\mathrm{p}$ value $<0.001$ ) and peak time ( $\mathrm{p}$ value $<0.001)$. This observation is thought to provide the easy access of the enzymes to the starch bodies which is advantageous during gelatinization and hydrolysis prior to ethanol fermentation.

\subsection{Saccharification}

The conversion rate and conversion efficiency of sorghum starch to glucose were measured to evaluate its digestibility. These were done using two sets of gelatinization, liquefaction and saccharification time $(5,6,30 \mathrm{~min}$ and 5, 10, $60 \mathrm{~min})$ and SPEZYME ${ }^{\circ}$ XTRA and G-ZYME 480 Ethanol enzyme concentration (60 AAU with 1.7 GAU and 1270 AAU with 34.6 GAU per $\mathrm{g}$ of flour). The initial rate of conversion illustrates how fast the starch was being converted to glucose using a reduced enzyme concentration and reaction time while efficiency of conversion measures the overall accessibility and availability of starch when complete enzymatic hydrolysis and saccharification have been achieved.

Table 5 shows the rate and efficiency of enzymatic conversion to glucose of the starch from the different digestible groups of sorghum. The conversion rate of the HD lines was about $18 \%$ faster and around 15\% more efficient than the ND lines under the conditions of the experiment. This implies that the HD line has higher starch accessibility and digestibility during enzymatic conversion compared to ND lines.

The ANOVA showed that there was a significant difference in rate ( $\mathrm{p}$ value $<$ 0.001 ) and efficiency ( $p$ value $<0.003$ ) of starch conversion to glucose among digestible groups (Table 6). However, the rate and efficiency of both the parent and offspring from the same digestible group did not significantly differ as shown by the LSD test in Table 5 .

Table 5. Rate and efficiency of starch enzymatic conversion to glucose among digestible groups.

\begin{tabular}{|c|c|c|c|c|}
\hline \multirow{3}{*}{$\begin{array}{l}\% \text { Yield } \\
\text { Glucose }\end{array}$} & \multicolumn{4}{|c|}{ Digestible Group } \\
\hline & \multicolumn{2}{|c|}{ Parent } & \multicolumn{2}{|c|}{ Offspring } \\
\hline & HD & ND & HD & ND \\
\hline Conversion (after $30 \mathrm{~min}$ ) & $39.42^{\mathrm{a}}$ & $32.38^{\mathrm{b}}$ & $38.91^{\mathrm{a}}$ & $33.36^{\mathrm{b}}$ \\
\hline Conversion efficiency (after $1 \mathrm{~h}$ ) & $84.65^{\mathrm{a}}$ & $74.29^{\mathrm{b}}$ & $82.11^{\mathrm{a}}$ & $71.08^{b}$ \\
\hline
\end{tabular}

Note: Means with the same letter in the same row are not significantly different using LSD $(\alpha=0.05)$. 
Table 6. Mean squares from ANOVA of rate and efficiency of starch enzymatic conversion to glucose among digestible groups.

\begin{tabular}{cccccc}
\hline & Sum of Squares & df & Mean Square & F & Sig. \\
\hline Glucose Conversion Rate & 297.836 & 3 & 99.27868 & 11.25151 & 0.00003 \\
Glucose Conversion Efficiency & 1684.829 & 3 & 561.6098 & 7.401588 & 0.00034 \\
\hline
\end{tabular}

The increased protein digestibility of the HDGS most likely improved its starch digestibility and increased its rate of conversion and total glucose yield during saccharification. This is supported by the highly significant correlation between turbidity and rate of glucose conversion ( $p$ value $<0.001$ ) and between turbidity and efficiency of enzymatic conversion ( $\mathrm{p}$ value $<0.001)$ conducted.

\subsection{Ethanol Fermentation}

Using $100 \mathrm{ml}$ fermentation volume with $30 \%$ dry sorghum flour, the ethanol concentration (\%v/v) after 24,48 and $72 \mathrm{~h}$ simultaneous saccharification and fermentation (SSF) of 18 sorghum cultivars are shown in Figure 4. Ethanol yields were in the range of $5.1 \%-9.6 \%, 9.2 \%-13.1 \%$ and $11.2 \%-13.2 \%(\mathrm{v} / \mathrm{v})$ after 24, 48 and $72 \mathrm{~h} \mathrm{SSF}$, respectively. Assuming $1 \mathrm{~g}$ of starch could be hydrolyzed into $1.11 \mathrm{~g}$ glucose and each gram of glucose could produce $0.511 \mathrm{~g}$ of ethanol, the corresponding fermentation efficiency of each variety was calculated. The \% ethanol yield is normally used to indicate the efficiency of ethanol production [22].

Analysis of variance (ANOVA) at $95 \%$ confidence level confirms that there is a significant difference in fermentation efficiency between digestible groups after 24 and $48 \mathrm{~h}$ of fermentation ( $\mathrm{p}$ value $<0.001$ and $\mathrm{p}$ value $<0.0033$, respectively) but not after $72 \mathrm{~h}$ of SSF ( $\mathrm{p}$ value $=0.1067)($ Table 7$)$. Least significant difference (LSD) test in Table 8 shows that \% ethanol yield for both parent and offspring from the same digestible group are not significantly different throughout the 72 $\mathrm{h}$ of fermentation.

When HD lines were used, independent t-test at $\alpha=0.05$ shows that there is a significant difference in \% ethanol yield between 24 and $48 \mathrm{~h} \mathrm{(50 \%} \mathrm{and} \mathrm{65 \%}$ ethanol yield, respectively) and no significant difference between 48 and $72 \mathrm{~h}$ (65\% and 65\% ethanol yield, respectively). However, when ND lines were utilized, significant increase in \% ethanol yield can be observed until $72 \mathrm{~h}$ of SSF (38\%, 58\% and $62 \%$ ethanol yield at 24,48 and $72 \mathrm{~h} \mathrm{SSF}$, respectively). Results only show that $\mathrm{HD}$ sorghum lines have faster rate of conversion and shorter reaction time needed to achieve completion than ND sorghum lines. Thus, HD lines have significantly higher \% ethanol yield than the ND lines if fermentation time will be shortened to $48 \mathrm{~h}$.

Higher fermentation efficiency means higher starch conversion rate. This hypothesis is supported by positive significant correlation between rate of glucose conversion and \% ethanol yield after 24 and $48 \mathrm{~h} \mathrm{SSF}$ ( $\mathrm{r}$ value $=0.402$ and $\mathrm{r}$ value $=0.357$, respectively). Also, the altered protein matrix in the genetically 


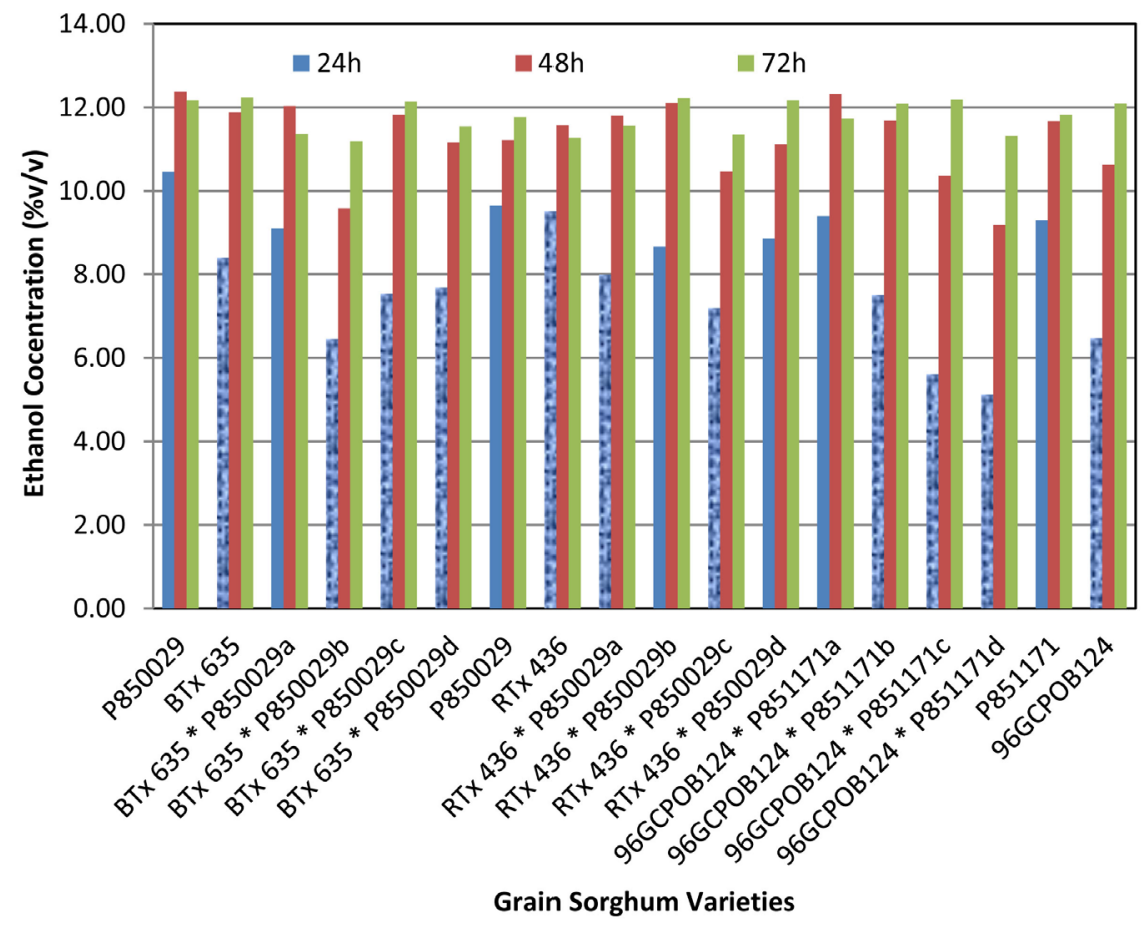

Figure 4. Ethanol concentrations (\%v/v) at 24, 48 and $72 \mathrm{~h}$ SSF using the 18 sorghum cultivars. ( $\square$ HD lines and 眐 ND lines.)

Table 7. Mean squares from ANOVA of \% ethanol yield at 24, 48 and $72 \mathrm{~h} \mathrm{SSF}$ among digestible groups.

\begin{tabular}{rccccc}
\hline & Sum of Squares & df & Mean Square & F & Sig. \\
\hline 24 h Fermentation & 1127.83 & 3 & 375.9435 & 12.06638 & 0.00002 \\
48 h Fermentation & 453.7155 & 3 & 151.2385 & 5.621919 & 0.00327 \\
72 h Fermentation & 62.98735 & 3 & 20.99578 & 2.204339 & 0.10673 \\
\hline
\end{tabular}

Table 8. Percent ethanol yield after 24, 48 and $72 \mathrm{~h}$ fermentation among digestible group.

\begin{tabular}{ccccc}
\hline \multirow{2}{*}{$\%$ Yield } & \multicolumn{4}{c}{ Digestible Group } \\
\cline { 2 - 5 } & \multicolumn{3}{c}{ Parent } & Offspring \\
\hline Ethanol & HD & ND & ND \\
\hline 24 h Fermentation & $50.06^{\mathrm{a}}$ & $42.59^{\mathrm{b}}$ & $50.00^{\mathrm{a}}$ & $37.51^{\mathrm{b}}$ \\
48 h Fermentation & $64.35^{\mathrm{a}}$ & $59.59^{\mathrm{b}}$ & $67.11^{\mathrm{a}}$ & $58.11^{\mathrm{b}}$ \\
72 h Fermentation & $65.35^{\mathrm{a}}$ & $62.29^{\mathrm{a}}$ & $64.99^{\mathrm{a}}$ & $62.41^{\mathrm{a}}$ \\
\hline
\end{tabular}

Note: Means with the same letter in the same row are not significantly different using LSD $(\alpha=0.05)$.

modified variety of grain sorghum, improved the sorghum starch digestibility during enzymatic hydrolysis and then contributed to the faster and higher starch conversion to glucose and ultimately to ethanol. This hypothesis is also supported by highly significant correlation between turbidity and \% ethanol yield after 24,48 and $72 \mathrm{~h} \mathrm{SSF}$ ( $\mathrm{r}$ values $=-0.617,-0.550$, and -0.426 , respectively). 
Ethanol production from dry milled HDGS, NDGS and corn using simultaneous saccharification and fermentation at 30\% dry solid is shown in Figure 5. Among the three substrates, the HDGS gave the highest ethanol yield all throughout the first $48 \mathrm{~h}$ of fermentation. Results suggest that HDGS starch is more digestible than corn starch and NDGS. HD lines also have shorter time of conversion which has been completed within $48 \mathrm{~h}$ of fermentation and faster and higher starch conversion to glucose and ultimately to ethanol than corn and NDGS. Since sorghum has lower demand as food, the new variety of highly digestible grain sorghum could very well serve as a viable substitute for corn in ethanol production.

Increasing the dry solid concentration from $22 \%$ to $30 \%(\mathrm{w} / \mathrm{v})$ increases the ethanol yield by almost $60 \%(\mathrm{v} / \mathrm{v})$ of the original. This will allow considerable saving of water, reduced distillation cost and increased ethanol production with given plant capacity and labor cost [23]. However, fermentation efficiency generally decreases as substrate concentration increases [22]. Results showed that the overall \% ethanol yield decreases by almost $30 \%$ when dry solid concentration is increased from $22 \%$ to $30 \%(\mathrm{w} / \mathrm{v})$.

Since fermentation in this study was carried out in shake flasks, conditions may not be optimal to ensure complete fermentation. In this study, microbial counts in all fermentation were maintained with $10^{7} \mathrm{cfu} / \mathrm{ml}$ though decrease in cell viability was observed after 48 and 72 . Stressful environment for yeast includes high solute and ethanol concentration, low $\mathrm{pH}$ and production of co products like acetic and lactic acid [4]. In order to maximize the benefit of high dry solid fermentation, further research is necessary to determine the optimum processing parameters and to improve the utilization of starch. High gravity fermentation under SSF has its potential of limited contamination and reduced osmotic stress to the yeast, because glucose is consumed as it formed.

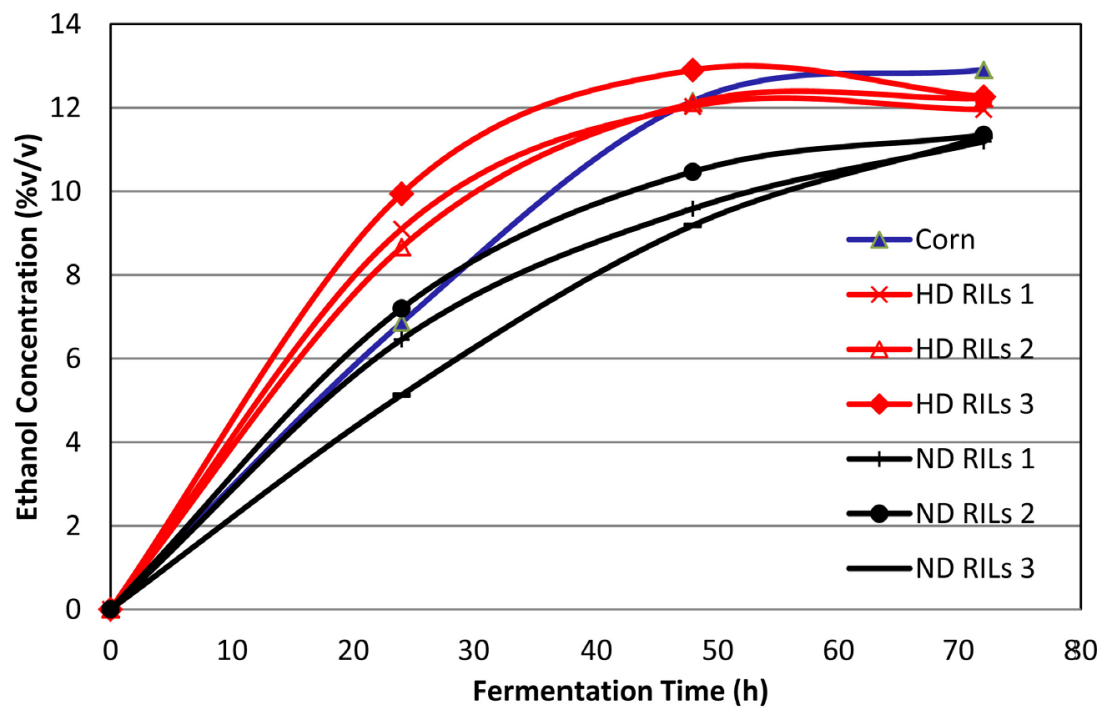

Figure 5. Comparison of ethanol concentration during $72 \mathrm{~h}$ SSF of HDGS, NDGS and corn at $30 \%$ dry solid. 


\subsection{Particle Size Distribution of Flour}

Mass median diameter (MMD) was used as a means of expressing and comparing particle size on a statistical basis. The geometric standard deviation (GSD) on the other hand was used to show how spread out are the particle sizes. Generally, it is assumed that attrition grinding or hammer milling of grains will result in sigmoidal particle size distribution (PSD) [20]. But, from the Malvern analysis, sorghum flour that was milled under $1 \mathrm{~mm}$ screen opening showed that it is a bimodal distribution (Figure 6).

The proportions of each distribution which have a particle size range of 3 to $60 \mu \mathrm{m}$ and 60 to $1000 \mu \mathrm{m}$, were calculated using the Malvern cumulative plot (Figure 7). Independent t-test for equality of means at $95 \%$ shows that there is a significant difference ( $\mathrm{p}$ value $<0.001$ ) between HD and ND flour in the percentage of each size range. HD flour has a significantly higher portion of 0 to $60 \mu \mathrm{m}$ $(33 \% \pm 7 \% \mathrm{w} / \mathrm{w})$ and significantly lower portions of 60 to $1000 \mu \mathrm{m}(67 \% \pm 6 \%$ $\mathrm{w} / \mathrm{w})$ than the ND flour $(18 \% \pm 7 \% \mathrm{w} / \mathrm{w}$ and $82 \% \pm 6 \% \mathrm{w} / \mathrm{w}$, respectively).

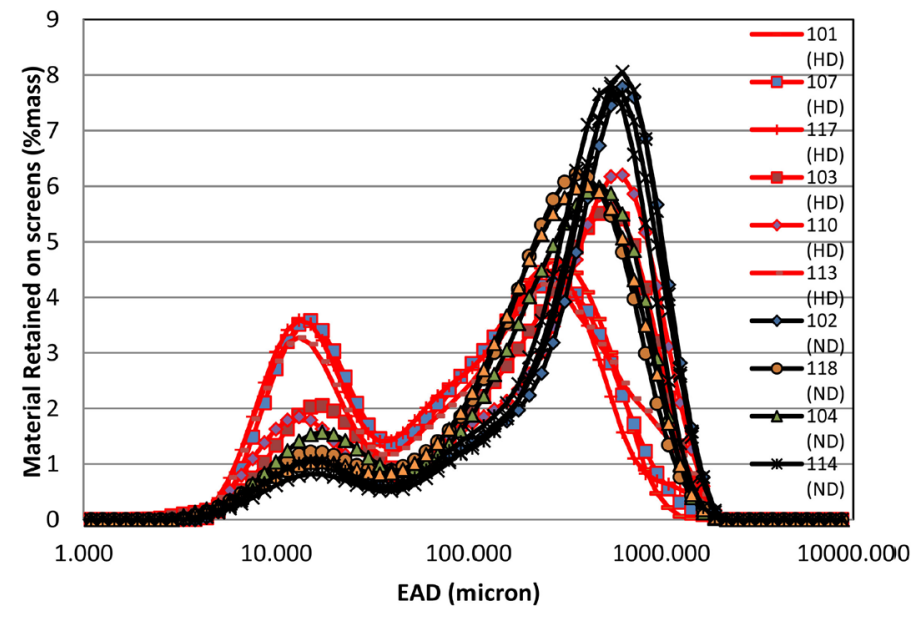

Figure 6. Particle size distribution of sorghum flour samples.

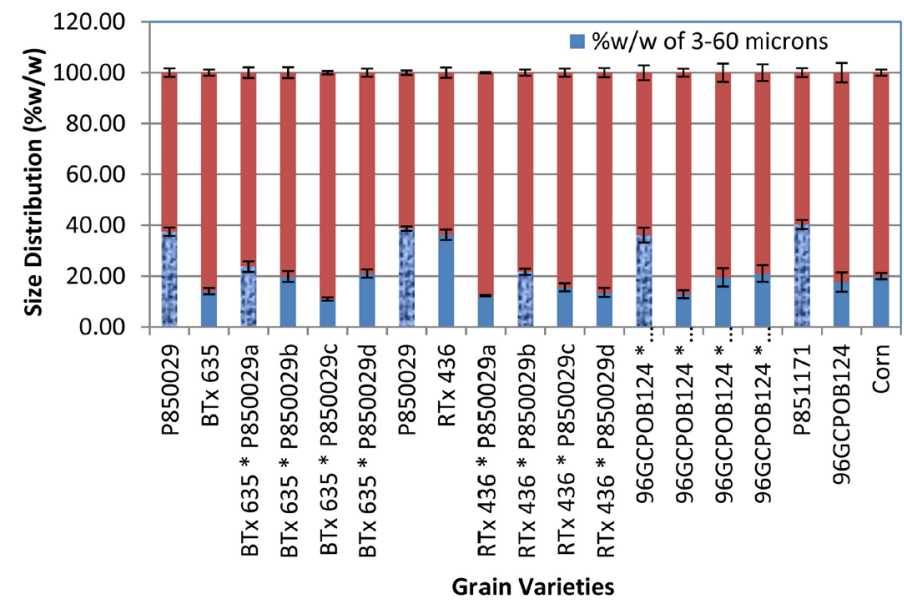

Figure 7. Percentage $(\% \mathrm{w} / \mathrm{w})$ of the bimodal distribution which has a particle size range of 3 to $60 \mu \mathrm{m}$ and 60 to $1000 \mu \mathrm{m}$. ( $\square$ HD lines and $\mathrm{H}^{\mathrm{n}} \mathrm{ND}$ lines.) 
The MMD and the GSD for each size range were also analyzed. LSD test in Table 9 shows that MMD and GSD of parent and offspring from the same digestible group are significantly different for coarse particles but not with fines. Analysis of variance (ANOVA) at 95\% confidence level confirms that there is no significant difference in MMD among digestible groups for 3 to $60 \mu \mathrm{m}$ size range but significantly different for 60 to $1000 \mu \mathrm{m}$ range (Table 10).

The PSD of sorghum flour samples shows that HD lines has greater portion of fine particles (about 3 to $60 \mu \mathrm{m}$ ) and lesser amount of coarse particles (about 60 to $1000 \mu \mathrm{m}$ ) than ND lines when hammer-milled using $1 \mathrm{~mm}$ screen openings. The physical characteristics of grain, such as kernel hardness and endosperm texture, have significant association with particle size distribution ( $\mathrm{r}$ value $=$ 0.424 and $r$ value $=-0.439$ ). It could be deduced that $\mathrm{HD}$ grains break easily than the ND because HD RILs have soft and floury endosperm matrix. This is also supported by the LSD results in Table 9. HD parent has the smallest MMD (15.40 and 226.63 for $0-60 \mu \mathrm{m}$ and $60-1000 \mu \mathrm{m}$ ) while ND offspring has the largest MMD $(447 \mu \mathrm{m})$. Though MMD of HD offspring is not significantly different in with ND parent, the HD offspring has the significantly highest GSD, meaning with most variation of particle size among the digestible groups.

Fineness of grind influences the amount of sugar formed due to variation in surface area of the flour. If particle is too large, starch granules are not easily gelatinized, forming fewer fermentable sugars [6]. The hypothesis that finer particle has faster and higher glucose yield is supported by highly significant

Table 9. Average MMD and GSD among digestible group.

\begin{tabular}{ccccc}
\hline & \multicolumn{4}{c}{ Digestible Group } \\
\cline { 2 - 5 } Properties & \multicolumn{3}{c}{ Parent } & Offspring \\
\cline { 2 - 5 } & HD & ND & ND \\
\hline 0 to $60 \mu \mathrm{m}$ range & $15.40^{\mathrm{a}}$ & $15.21^{\mathrm{a}}$ & $15.83^{\mathrm{a}}$ & $15.28^{\mathrm{a}}$ \\
MMD & $1.51^{\mathrm{a}}$ & $1.71^{\mathrm{b}}$ & $1.64^{\mathrm{b}}$ & $1.76^{\mathrm{c}}$ \\
GSD & & & & \\
60 to $1000 \mu \mathrm{m}$ range & $226.63^{\mathrm{a}}$ & $406.68^{\mathrm{b}}$ & $312.20^{\mathrm{b}}$ & $365.97^{\mathrm{c}}$ \\
MMD & $2.08^{\mathrm{a}}$ & $2.05^{\mathrm{b}}$ & $2.29^{\mathrm{b}}$ & $2.07^{\mathrm{c}}$ \\
\hline GSD & $5.05)^{\circ}$
\end{tabular}

Note: Means with the same letter in the same row are not significantly different using LSD $(\alpha=0.05)$.

Table 10. Mean squares from ANOVA average MMD and GSD among digestible group.

\begin{tabular}{|c|c|c|c|c|c|}
\hline & Sum of Squares & $\mathrm{df}$ & Mean Square & $\mathrm{F}$ & Sig. \\
\hline MMD (from $3-60 \mu \mathrm{m}$ ) & 1.522277 & 3 & 0.507426 & 0.713205 & 0.552066 \\
\hline GSD (from $3-60 \mu \mathrm{m})$ & 0.295016 & 3 & 0.098339 & 9.950877 & 0.000113 \\
\hline MMD (from $60-1000 \mu \mathrm{m})$ & 118453.2 & 3 & 39484.42 & 6.853663 & 0.00125 \\
\hline GSD (from $60-1000 \mu \mathrm{m})$ & 0.260656 & 3 & 0.086885 & 7.329964 & 0.000842 \\
\hline
\end{tabular}


correlation between MMD and glucose conversion efficiency ( $\mathrm{r}$ value $=-0.742$ ) and significant correlation between MMD and rate of glucose conversion during saccharification ( $\mathrm{r}$ value $=-0.524$ ). It was also reported that particle size has an effect on ethanol yield. Final ethanol concentration can increase by $22 \%$ if corn flour grinding screen size is decreased from 5 to $0.5 \mathrm{~mm}$ [6]. However, in this study, the difference in particle size of HD and ND has no significant effect on ethanol yield. We could therefore hypothesize that variation in particle size below 500 microns has no significant effect in ethanol yield.

\section{Conclusions}

HD lines have more flour-like endosperm texture, softer kernels and lower starch content than the ND lines but are not significantly different in protein, moisture, ash content, kernel size and flour density. RVA results show that HD lines have lower pasting temperature and faster rate of gelatinization compared to ND lines. Hence, HD lines had an advantage over ND lines if used as a feedstock for bio-ethanol production. The increased protein digestibility of the HDGS significantly improved its starch pasting property and starch digestibility (increased its rate of conversion and total glucose yield during saccharification) which further increases the ethanol yield. Results also show that HD sorghum lines have faster rate of conversion and shorter reaction time needed to achieve completion during fermentation than ND sorghum lines and corn.

Increasing the dry solid concentration from $22 \%$ to $30 \%(\mathrm{w} / \mathrm{v})$ increases the ethanol yield from $8 \% \mathrm{v} / \mathrm{v}$ to $13 \% \mathrm{v} / \mathrm{v}$. This will allow considerable saving of water, reduced distillation cost and increased ethanol production with given plant capacity and labor cost [23]. However, fermentation efficiency generally decreases as substrate concentration increases [22].

Fineness of grind influences the amount of sugar formed due to variation in surface area of the flour. The hypothesis that finer particles have faster and higher glucose yield is supported by highly significant correlation between MMD and glucose conversion efficiency. There is also significant correlation between MMD and rate of glucose conversion during saccharification.

Particle reduction in particle size from $5 \mathrm{~mm}$ to $0.5 \mathrm{~mm}$ size has a significant increase on ethanol yield [6]. However, in this study, variation in particle size below 500 microns has no longer a significant effect in ethanol yield. Results showed that the difference in particle size of HD (156 to 339 microns) and ND (375 to 447 microns) has no significant correlation on ethanol yield.

HDGS has lower energy input required during grinding, gelatinization and hydrolysis of starch granules. Improved protein digestibility also increased bioavailability of starch during enzymatic hydrolysis and ethanol yield. Since sorghum has lower demand as food, the new variety of highly digestible grain sorghum could very well serve as a viable substitute for corn in ethanol production. HDGS requires lower energy inputs during grinding, gelatinization and hydrolysis of starch granules compared to NDGS. Since sorghum has lower de- 
mand as food, this new variety of grain sorghum could be a viable supplement for corn for a much economical production of ethanol.

\section{Recommendations}

Further research is necessary to determine the optimum bio-ethanol processing parameters to attain maximum utilization of starch during fermentation for only the top varieties identified in this study.

\section{Acknowledgements}

We acknowledge the Texas A \& M University (TAMU-AgriLife) AgriLife Research for financial support of this study. Dr. Dirk Hays and Ostilio Portillo of the Sorghum Breeding Program at the Soils and Crop Science at TAMU provided the grain sorghum varieties and the corresponding protein digestibility properties of each line. We also acknowledge Genencor International, Inc. for providing the proper enzymes for this study.

\section{Conflicts of Interest}

The authors declare no conflicts of interest regarding the publication of this paper.

\section{References}

[1] Mohammadi, S., Rabani, H. and Honarmand, S.J. (2015) The Effect of Bioethanol on Pollutants and Engine Fuel Consumption. Research Journal of Fisheries and Hydrobiology, 10, 234-244.

[2] Energy Efficiency and Renewable Energy (EERE) (2016) Bioenergy Multi-Year Program. US Department of Energy (USDOE), Washington DC. https://www.energy.gov/sites/prod/files/2016/07/f33/mypp march2016.pdf

[3] Capareda, S.C. (2014) Introduction to Biomass Energy Conversions. CRC Press, Taylor and Francis Group, Boca Raton. https://doi.org/10.1201/b15089

[4] Nichols, N.N., Monceaux, D.A., Dien, B.S. and Bothast, R.J. (2008) Production of Ethanol from Corn and Sugarcane. In: Bioenergy, ASM Press, Washington DC, 3-15. https://doi.org/10.1128/9781555815547.ch1

[5] US Renewable Fuel Association (RFA) (2008) Changing the Climate: Ethanol Industry Outlook 2008.

https://ethanolrfa.org/wp-content/uploads/2015/09/RFA Outlook 2008.pdf

[6] Naidu, K., Singh, V., Johnston, D.B., Rausch, K.D. and Tumbleson, M.E. (2007) Effects of Ground Corn Particle Size on Ethanol Yield and Thin Stillage. Cereal Chemistry, 84, 6-9. https://doi.org/10.1094/CCHEM-84-1-0006

[7] Singh, V., Batie, C.J., Aux, G.W., Rausch, K.D. and Miller, C. (2006) Dry-Grind Processing of Corn with Endogenous Liquefaction Enzymes. Cereal Chemistry, 83, 317-320. https://doi.org/10.1094/CC-83-0317

[8] Smith, R. (2008) Planting Date: Critical Decision in Grain Sorghum Yield Potential. Southwest Farm Press, New Mexico. http://southwestfarmpress.com

[9] Sullivan, P. (2003) Conservation Tillage. Appropriate Technology Transfer for Rural Area Publication \# CT105. 
http://www.nysenvirothon.org/wp-content/uploads/2019event conservationtillage. pdf

[10] Hoseney, R.C. (1994) Principles of Cereal Science and Technology. In: Structure of Cereals, 2nd Edition, American Association of Cereal Chemists, St. Paul, 327 p.

[11] Kulp, K. and Ponte, J.G. (2000) Handbook of Cereal Science and Technology. 2nd Edition, Marcel Dekker Inc., New York.

[12] Zhan, X., Wang, D., Sun, X.S., Kim, S. and Fung, D.Y.C. (2003) Lactic acid Production Using Extrusion-Cooked Grain Sorghum. Transactions of the ASAE, 46, 589-593. https://doi.org/10.13031/2013.12914

[13] Duodu, K.G., Taylor, J.R.N., Belton, P.S. and Hamaker, B.R. (2003) Factors Affecting Sorghum Protein Digestibility. Journal of Cereal Science, 38, 117-131. https://doi.org/10.1016/S0733-5210(03)00016-X

[14] Beta, T., Corke, H., Rooney, L.W. and Taylor, J.R.N. (2000) Starch Properties as Affected by Sorghum Grain. Journal of the Science of Food and Agriculture, 81, 245-251. https://doi.org/10.1002/1097-0010(20010115)81:2<245::AID-ISFA805>3.0.CO;2-S

[15] Oria, M.P., Hamaker, B.R., Axtell, J.D. and Huang, C. (2000) A Highly Digestible Sorghum Mutant Cultivar Exhibits a Unique Folded Structure of Endosperm Protein Bodies. Proceedings of the National Academy of Sciences, 97, 5065-5070. https://doi.org/10.1073/pnas.080076297

[16] Zhang, G. and Hamaker, B.R. (1998) Low $\alpha$-Amylase Digestibility of Cooked Sorghum Flours and the Effect of Protein. Cereal Chemistry, 75, 710-713. https://doi.org/10.1094/CCHEM.1998.75.5.710

[17] Portillo, O.R. (2007) A Mycological Assessment of Highly Digestible Protein Sorghum Lines. MS Thesis, Texas A \& M University, Department of Soil and Crop Sciences, College Station.

[18] Rooney, W.L., Blumenthal, J., Bean, B. and Mullet, J.E. (2007) Designing Sorghum as a Dedicated Bioenergy Feedstock. Biofuels, Bioproducts and Biorefining, 1, 147-157. https://doi.org/10.1002/bbb.15

[19] American Association of Cereal Chemists (2000) Methods 44-15A, 46-30, and 76-13. In: Approved Methods of the AACC, 10th Edition, AACC, St. Paul.

[20] Faulkner, W.B. (2004) The Effect of Inlet Velocity and Barrel Diameter on Cyclone Performance. MS Thesis, Texas A \& M University, Department of Biological and Agricultural Engineering, College Station.

[21] Sluiter, A. and Sluiter, J. (2005) NREL Laboratory Analytical Procedure (LAP-016): Determination of Starch in Solid Biomass Samples by HPLC. National Renewable Energy Laboratory, Golden. http://www.nrel.gov/biomass/pdfs/42624.pdf

[22] Zhan, X., Wang, D., Bean, S.R., Mo, X., Sun, X.S. and Boyle, D. (2006) Ethanol Production from Supercritical-Fluid-Extrusion Cooked Sorghum. Industrial Crops and Products, 23, 304-310. https://doi.org/10.1016/j.indcrop.2005.09.001

[23] Bvochora, J.M., Read, J.S. and Zvauya, R. (2000) Application of Very High Gravity Technology to the Cofermentation of Sweet Stem Sorghum Juice and Sorghum Grain. Industrial Crops and Products, 11, 11-17. https://doi.org/10.1016/S0926-6690(99)00029-1 